\title{
Moving Texts, Migrating People and Minority Languages
}

Borodo, Michal et AL. (Eds). 2017. Moving Texts, Migrating People and Minority Languages. Springer.

Reviewed by MEENU SABU

The concept of migration has been central to the discourses on diaspora studies, multiligualism, endangered minority languages, resistance literature, globalization, language politics and postcolonialism. Movement of people from one place to another often ensue the creation of hybrid spaces and intercultural exchanges, which provide scope for inter-language communication. Occurrence of more than one language in geographical proximity can lead to a symbiotic and unequal relationship between languages, where certain languages may gain precedence over others in the power-struggle.

The book Moving Texts, Migrating People and Minority Languages edited by Michal Borodo, Juliane House and Wojciech Wachowski is a collection of essays which studies translation in this context of human migration and languagepolitics. It is published as part of the series "New Frontiers in Translation Studies" edited by Defeng Li. The book is a collection of twelve essays by twelve different scholars organised under three heads. These essays, with their common thread of migration, address multifarious issues related to translation.

The first part, titled 'Translation, Minority Languages and Multilingualism,' touch upon topics like the survival strategies of endangered languages and role of translation and multilingualism in resistance literature. Migrant literature and the linguistic and cultural conflicts embedded in them form the second part of the book titled 'Language, Translation and the Migrant Experience.' The third section titled 'Texts, Concepts and People on the Move' comprises four essays which focus 
on how texts and concepts move in the process of translation to reach the target audience.

The first essay of the first part of the book deals with the translation of children's literature from and into Basque, a nonIndo-European language spoken in two autonomous areas of Spain and three provinces of French. The author demonstrates how direct and indirect translations of children's literature vary both in the case of translations from and into Basque. The second and third essays also deal with minority languages: The Neo-Aramaic Language Turoyo and Mariupolitan Greek respectively. While the second essay examines the role of translation in corpus planning by focussing on the processes that went into the translation of the children's classic The Little Prince into Turoyo, the third delineates the role of the shared history of oppression in bringing forth translations of resistance poetry between two non-global languages, Mariupolitan Greekand Ukrainian. The fourth essay of the section compares French Hip-Hop with Arabic diaspora HipHop and investigates their role in asserting the cultural identity among the Arab diaspora in Europe.

The four essays of the second part of the book comprise studies on works motivated by experiences of migration. The first essay makes a comparative study of the paratexts of Italian and English translations of Hella Haasse's The Tea Lords, a Dutch novel or repatriation. The author shows how a text from a former coloniser's perspective is introduced in the two languages, one without a direct colonial experience and another with a strong colonial legacy. The second essay examines the Hungarian-French language Shift in Agota Kristof's novel The Illiterate, which deals with the author's own struggle after she crossed the borders to Austria from Hungary during the Hungarian uprising of 1956. The third and the fourth essays assess the migrant literature of Italian- 
Canadian and Albanian-Austrian migrants respectively in terms of their desperate attempts at both retaining the native language as well as learning the language of the host-land.

The third section contains four essays illustrating the mutual influence of translation and 'movement.' The first essay investigates how Yan Fu's Chinese translation of Thomas Huxley's Evolution was intended to move the Chinese empire. The second essay researches on the issues involved in catering to diverse audience while translating Peter Ackroyd's The Death of King Arthur, a text which in itself is a reworking of several source texts. The complications involved in the translation of philosophical texts form the next essay. The writer analyses the impact of translating Heidegger's term Dasein in Bosnian/Croatian/Montenegrin/Serbian Translations of Being and Time. The fourth essay of the section is an attempt to bring to light the contributions of migrant writers to the corpus of children's literature in the Anglophone world. Thus, in the final essay the book comes back to discussing translations of children's literature in the context of migration, which it started in the beginning.

The book Moving Texts, Migrating People and Minority Languages is thus an assemblage of miscellaneous essays in the field of translation studies. Each chapter, an independent research endeavour in itself, begins by justifying the relevance of the study by detailing the research gaps and limitations of the previous researches, if at all there were any, of the respective areas they investigate. Since the chapters follows a well -documented structure and add a list of' reference materials at the end, it provides scope for the readers proceed beyond the text.

Throughout the book the authors have given special attention in establishing the role of socio-political factors in translation in the particular contexts. In most cases, the social and 
linguistic background is explained before proceeding to the main argument. But while doing so, some writers deviates into focussing more on introducing the topic rather than topic itself and thereby providing only a glance and failing to go beyond it. This deviation happens mostly in the case of essays works done on non-European languages, especially the works on minority languages. So, it would not be groundless if one senses the presence of euro-centrism operating within the text.

In spite of the limitations the book Moving Texts, Migrating People and Minority Languages has successfully brought together into its canvas areas as diverse as minority languages, children's literature, migrant literature, resistance literature and language-politics. Despite the unrelated themes dealt upon, the book as a whole exhibit an organic unity. Thus, with its simple and lucid style of rendering, Moving Texts, Migrating People and Minority Languages is a good read for those interested in getting informed about translation in general as well as for researchers working in the specific areas of translation studies covered in the book. 